commitments, not least by treating other people, and competing ideas, not just with respect, but also with a kind of joy.

\section{Cass R. Sunstein}

Others can speak with more authority about Iris Marion Young as a scholar and teacher but I can testify whole-heartedly that she was a wonderful colleague. The congenial collegial collaboration of the distinguished theorist of the politics of difference and the scholar of Machiavelli, Locke, and Strauss may have surprised some observers - it may even have surprised the two of us. As soon as Iris arrived at Chicago we had lunch to discuss the state of political theory in the department and the university, the political theory workshop, and the Classics of Social and Political Thought common core sequence, and we hit it off at once. I was immediately won over by her openmindedness, enthusiasm, and solicitude for students and colleagues. Though I do not find academic administrative tasks uniformly enjoyable, I always found it a real pleasure to work with Iris whether on establishing and administering field exams in political theory, running our workshop and common core sequence, performing the duties of an ad hoc committee, or planning for faculty recruitment. She was contagiously cheerful even in trying circumstances. When she rewrote my prose, my pride of authorship gave way to gratitude for her straightforward improvements. She was always ready to do more than her share without a hint of self-righteousness, in a gracious way that inspired one to do likewise. She was a good citizen who cared deeply about the local as well as the global common good because she was a good person: fair-minded and good-hearted to the core. I can hardly believe she is gone and I know I will miss her terribly.

\section{Nathan Tarcov}

\section{Harmon Zeigler}

L. Harmon Zeigler died from a massive heart attack in Tacoma on July 31, 2006. He is survived by his wife of 50 years, Pat; his two children, Mike and Amanda; and three grandchildren, Ben, Zoe and Ruby.

Harmon was born in Savannah, Georgia on March 9, 1936. Among his earliest—and, for him, perhaps his proudest - achievements was playing for the Georgia Bulldogs, an athletic career that was, sadly, ended early by a knee injury. He received a B.A. from Emory University in 1957, an M.A. from the
University of Illinois, Champaign/ Urbana in 1958, and a Ph.D. also from Illinois in 1960 - the latter completed when he was only 24 . Following graduation, he took positions at Florida State University (1960-1961); at Emory University (1961-1963); and at the University of Georgia (1963-1964) before coming as an associate professor to the political science department and the Center for the Advanced Study of Educational Administration at the University of Oregon in 1964. He became a full professor of political science at the University of Oregon and director of the University's Center for the Educational Policy and Management in 1967. After 21 years at Oregon, he took an endowed chair at the University of Puget Sound.

Throughout his career Harmon held many visiting professorships, including at the University of Washington (1966), the University of Oslo (1972); the University of Sydney, Australia (1978) and the State University of New York, Stony Brook (1979).

He left a very substantial legacy of scholarship in political science. To several generations of political science undergraduates, he was surely best known for his very successful text with Tom Dye, The Irony of Democracy: An Uncommon Introduction to American Politics, whose first edition appeared in 1970 and whose $13^{\text {th }}$ edition appeared in 2005. The book's success derived in part, no doubt, from the clarity and grace of its writing, but most certainly also from the "uncommon" fact that, as a text, it not only provided systematic coverage of the major institutions of American democracy, but also that it argued a thesis - that government in the late-twentieth and twenty-first centuries is, contrary to myth, government by elites, not masses. Based firmly on contemporary scholarship, The Irony challenged students to rethink many of the assumptions about American government on which they had been raised.

His scholarly record was formidable. Writing alone and with various collaborators, he published more than 30 books and monographs and many articles, often in the discipline's leading journals. His major substantive focus was on state and local politics, on electoral behavior, and, in particular, on educational policy and politics; one recurring theme in the latter domain was the governance of American schools, and the politics of educational governance - a field that he substantially pioneered. But he also branched well beyond those topics, perhaps most notably undertaking a major comparative analysis of interest groups and conflict management in his Pluralism, Corporatism, and Confucianism: Political Associations and
Conflict Regulation in the United States, Europe and Taiwan; also, writing with Keith Pool, addressing the changing role of women in American elections in their Women, Public Opinion and Politics: The Changing Political Attitudes of American Women (Longman) and "The Diffusion of Feminist Ideology" in Political Behavior (1981). Harmon was pluralistic in methodological terms, but his openness to diverse theoretical perspectives in political science and neighboring disciplines was apparent to all his colleagues-he was endlessly curious about just what they were working on, even if remote from his own current interests - and the many people who met and talked with him at conferences.

Harmon was awarded research grants or fellowships from the Ford Foundation (1969); the John Simon Guggenheim Foundation (1969-1970); The National Institute of Education (1973-1976); The Earhart Foundation (1973-1974); Fulbright-Hays (to West Germany in 1977 and to Australia in 1978); the Pacific Cultural Foundation (1982); and the Spencer Foundation (1982). He served on many editorial boards and as a consultant for many journals and publishing companies. At the University of Oregon, he served on a wide range of departmental and university committees, in addition to being chair of the political science department from 1982-1985. Those of us who were in the department at that time remember his humor, wit, and charmwhich made department meetings events that (astonishingly!) were eagerly anticipated and, certainly, enjoyed. That humor, wit, and charm made him a wonderful friend and, with Pat, a no less wonderful host and dinner companion.

Harmon collaborated with a remarkable array of scholars-including (alphabetically) Alvin Boskoff, Mike Baer, T. L. Becker, Mick Boss, Tom R. Dye, L. A. Froman, Jr., John Grove, Michael Huelshoff, E. Kehoe, M. Kent Jennings, K. F. Johnson, Norman Luttbeg, Joseph Olexa, Wayne Peak, Keith Poole, J. Reisman, B. L. Smith, Harlan Strauss, T. L. Thorston, Harvey Tucker, Hendrik Van Dalen, and L. A. Wilson. Many of these were already leading scholars; others were Harmon's students who went on to important careers after graduation-in some cases including ongoing collaboration with Harmon himself.

Harmon Zeigler left a major intellectual legacy, but he also left many friends at Oregon and in the discipline more broadly, all of whom join his family in mourning his loss.

John Orbell University of Oregon 